\title{
Histology and Histomorphology of Hormone Treated Surati Buffalo Udder Tissue
}

\author{
${ }^{1,3}$ H.H. Mehta, ${ }^{1}$ A.K. Patel, ${ }^{1}$ K.N. Nandasana, \\ ${ }^{1}$ U.V. Ramani, ${ }^{1}$ P.G. Koringa, ${ }^{1}$ R.G. Shah, ${ }^{1}$ D.R. Barvalia, ${ }^{1}$ N. Kelawala, \\ ${ }^{1}$ D.B. Patil, ${ }^{1}$ D.N. Rank, ${ }^{1}$ C.G. Joshi, ${ }^{1}$ K.M. Panchal and ${ }^{2}$ Ramesh K. Kothari \\ ${ }^{1}$ Department of Animal Biotechnology, College of Veterinary Science and Animal Husbandry, \\ Anand Agricultural University, Anand: 388001, Gujarat, India \\ ${ }^{2}$ Department of Microbiology, Christ College, Affiliated to Saurashtra University, Rajkot-360 005, Gujarat, India \\ ${ }^{3}$ Department of Biotechnology, Shree P.M. Patel Institute of Integrated M.Sc., In Biotechnology, \\ Managed by Anand Peoples Medicare Society, Sardar Patel University, Anand, Gujarat, India
}

Received 2012-03-03, Revised 2013-06-07; Accepted 2013-07-11

\begin{abstract}
In the global dairy scenario, India has the distinction of being the largest milk producing nation of the total milk production of 100.9 million tons in $2006-2007$, about $55.6 \%$ has been contributed by buffalo. Buffalo is a more efficient milk producer than an indigenous cow. The present study was carried out to study the morphological changes associated with induced lactation in buffalo mammary gland tissue. Lactation was induced in four nonpregnant, non-lactating buffaloes by subcutaneous injections of estradiol-17 $\beta$ and progesterone for $10 \mathrm{~d}(@ 0.10$ and $0.25 \mathrm{mg} \mathrm{kg}^{-1}$ b. w./d) respectively and Dexamethasone (@ $0.028 \mathrm{mg} \mathrm{kg}^{-1}$ b.w./d) treatment was given on 17 th to 19 th d. Milking was initiated on day 20. Biopsies of mammary glands were collected on 0,7 th, 14th and 21st day from each animal. Hormonal treatment of mammary tissues of 0 days had abundant connective and adipose tissues with very sparse lobuloalveolar structures. On the 7th day, there was a decrease in stroma, increase in epithelial cell area with increased lobulo-alveolar architecture. There was an accumulation of intracellular and intra-luminal secretions with more lipid droplets. From 7 th to 21 st day, these changes were progressive although variable amongst buffaloes. The average size of the lobule, alveoli as well as the number and volume of alveoli were significantly increased on the 21 st day as compared to 0 day. Increase in size of lobule, alveoli and volume of alveoli and number of alveoli inferred that there was significant physiological changes in the ultrastructure of mammary gland of buffalo. These changes were similar to lactating mammary gland.
\end{abstract}

Keywords: Induction, Progesterone, Estrogen, Dexamethasone, Lactogenesis, Mammary Gland

\section{INTRODUCTION}

In Asia, buffalo has been an integral part of livestock agriculture for over the period of 5000 years producing animal draft power, milk, meat and hides. In the global dairy scenario, India has the distinction of being the largest milk producing nation, which can be mainly credited to buffaloes for achieving and maintaining this unique status of the total milk production of 100.9 million tons in 2006-2007, about
$55.6 \%$ has been contributed by buffalo. Buffalo is a more efficient milk producer than an indigenous cow. In India Parekh (2002) has worked on gross and microscopic studies of the udder of lactating and non-lactating, nonpregnant adult buffaloes. Patel et al. (2007a) have reported comparative histology of mammary gland of heifer, pregnant, lactating and dry buffaloes. They have also reported effect of bovine Somatotropin (bST) administration on the histology of mammary gland in lactating buffaloes (Patel et al., 2007b).

Corresponding Author: Ramesh K. Kothari, Department of Microbiology, Christ College, Affiliated to Saurashtra University, Rajkot-360 005, Gujarat, India Tel: 0091-9428288511 Fax: 0091-281-2570301 
Recent advances by (Smith et al., 1971; 1973) have reported in the arena of artificial induction of lactation in dairy animals by exogenously administered progesterone and estrogen which have been more successful than earlier investigations (Meites, 1961; Tucker, 1969; 1971; 1974). Many researchers have reported a successful induced lactation in bovines by short treatments of steroid hormones (Chakriyarat et al., 1978; Croom et al., 1976; Delouis et al., 1978; Erb et al., 1975; Howe et al., 1975; Fleming et al., 1986). Alifakiotis et al. (1980) reported induced lactation in dairy ewes by various brief hormone treatments. Head et al. (1975) had reported successful hormonal induction of lactation in sheep. Collier et al. (1975) reported similar success in cattle with dexamethasone in addition to estrogen and progesterone. Fleming et al. (1986) reported greater milk yield in the cows injected with Estradiol-17 $\beta$ and progesterone for 21 days instead of 7 days. Till date there is no report on the effect of estrogen and progesterone hormonal induction on the mammary gland tissue architecture of buffaloes.

The objective of the present study was to study the morphological changes associated with induced lactation in buffalo mammary gland tissue.

\section{MATERIALS AND METHODS}

\subsection{Animals}

Four non-lactating, non-pregnant Surti buffaloes were reared in standard conditions of animal husbandry. They were stall-fed with optimum nutrition diet.

\subsection{Hormones and Injections}

All animals were injected subcutaneously 1, 3, 5(10)-estratrien-3, $17 \beta$ diol (Estradiol $17 \beta$ ) and 4pregenen-3, 20 dione (progesterone) (Sigma Chemical Co) dissolved in absolute alcohol at dosages of $0.10 \mathrm{mg}$ and $0.25 \mathrm{mg} \mathrm{kg}^{-1}$ of body weight, respectively for ten days at 08.00 and $17.00 \mathrm{~h}$ (Smith and Schanbacher, 1973). From 17th to 19th day, the injection of Dexamethasone $\left(0.28 \mathrm{mg} \mathrm{kg}^{-1}\right.$ of b.wt.) was given once in a day (Collier et al., 1975). Initiation of lactogenesis was observed on the 20th day.

\subsection{Tissue Collection}

Buffaloes used for biopsy collection were given preoperative feed withdrawal for $12 \mathrm{~h}$. Bayrocin (enrofloxacin injection $10 \% 5 \mathrm{mg} \mathrm{kg}{ }^{-1}$ b.wt.) was injected $\mathrm{S} / \mathrm{C} .8 \mathrm{~h}$ prior to surgery as a prophylactic and Kosclot (ethamsylate injection 12.5\%, $4 \mathrm{mg} \mathrm{kg}^{-1}$ b.wt.) was injected intra-muscular 45 min prior to surgery as a haemostat. Inj. Xylaxin (@0.05 mg kg-1 b.wt,) I/V was used to obtain a mild sedation for the surgical procedure. The skin was prepared for aseptic surgery. The skin and subcutaneous tissue were desensitized by infiltrating local anesthesia using lignocaine hydrochloride injection $2 \%$ (Cadila Healthcare Ltd.) $9-10 \mathrm{~mL}$ around the mammary branches of pudenal nerve in hind quarter and mammary branches of genito-femoral nerve and ilioinguinal nerve in fore quarter. The biopsy was collected as per the surgical protocol described by Koringa et al. (2008) from right hind quarter of animal on the zero day of hormonal induction and treatment of estrogen and progesterone was initiated after the surgery for 10 days. Biopsies from remaining quarters were collected on the 7th, 14th and 21st day of hormonal induction using the same operative procedure from all the experimental animals.

\subsection{Histomorphological Study}

The tissue biopsies were washed with PBS for removing the traces of blood and divided into 5-6 pieces devoid of adipose tissues. For histomorphological study, all collected mammary tissues were fixed in $10 \%$ neutral buffered formalin, followed by routine tissue processing for paraffin embedding technique. The tissue sections of 6-8 $\mathrm{mm}$ thickness were cut and stained by haematoxylin and eosin stain (H and $\mathrm{E}$ stain) for detailed histological studies as per (Humason, 1967; Jones, 1966; Sanders, 1972). Serial sections from each block of tissue were examined, for evaluating histological appearance. Size (length and width) of the well defined lobules was calculated and derived in micron under low power (10X) objective. Number of alveoli were counted per microscopic field (each of 0.0770078 sq. $\mathrm{mm}$ area) selected under low power (10X) objective. Diameter of alveoli was measured under high power (40X) objective by a graduated eyepiece. Finally, average diameter was calculated in micron. The volume of alveoli was obtained by the formula $4 / 3 \pi r^{3}$, where $\pi=3.14, r$ is the radius of the alveoli.

\section{RESULTS}

The mammary gland is composed of the stroma and parenchyma. The stroma is made up of connective tissue. The parenchyma is composed of secretory units and the ramifying ductular system. The secretory unit of the mammary gland consists of an alveoli and alveolar ducts arising from them. Several groups of secretory units form lobules separated by connective tissue septae. The 
secretory tissue in the mammary gland is organized into lobules and each lobule contains about 150-220 microscopic alveoli (Panchal and Vyas, 2005). The alveoli are sack like structure where milk is synthesized and secreted. An alveolus is the discrete milk-producing unit. A single layer of secretory epithelial cells lines the lumen of the alveolus. The epithelial lining is surrounded by contractile myo-epithelial cells.

The present study was undertaken in four different stages of estrogen-progesterone induction in buffalo which included 0 day, 7 th day, 14th day and 21 st day of induction. The difference in the microstructure and micrometry of mammary gland among these stages of induction were studied and recorded.

\subsection{Micrometric Study}

The smaller and larger diameter of Lobule, volume of alveoli, length and width of the alveoli and the number of alveoli per square millimeter cross sectional area of the parenchyma were observed and recorded in all four different stages of induced lactating buffalo (Table 1).

\subsection{Diameter of Alveoli}

The alveoli were oval to elliptical in shape; hence, the smaller and larger diameters of alveoli were measured. The mean values of these measurements were worked out per lobule. The smaller diameter (width) of alveoli ranged from $0.414 \times 10^{3}$ to $1.490 \times 10^{3} \mu \mathrm{m}$ with an overall mean of $1.003 \times 10^{3} \mu \mathrm{m}$ in different stages of hormonal induction. The overall average values of smaller diameter of alveoli were $0.531 \times 10^{3} \mu \mathrm{m}, 0.828 \times 10^{3} \mu \mathrm{m}$, $1.188 \times 10^{3} \mu \mathrm{m}, 1.546 \times 10^{3} \mu \mathrm{m}$, on 0 day (control), 7 th day, 14th day and 21 st day respectively of hormonal induction. The alveoli with smaller diameter were significantly more at the 7 th day, 14 th day and 21 st day of hormonal induction as compared to control ( 0 day).

The larger diameter (length) of alveoli was ranging from $0.568 \times 10^{3}$ to $1.725 \times 10^{3} \mu \mathrm{m}$ with an average of $1.089 \times 10^{3} \mu \mathrm{m}$ in different stages of hormonal induction. The overall average values of the larger diameter of alveoli were $0.621 \mu \mathrm{m} \times 10^{3}, 0.845 \times 10^{3} \mu \mathrm{m}, 1.214 \times 10^{3}$ $\mu \mathrm{m}$ and $1.599 \times 10^{3} \mu \mathrm{m}$ are on the 0th day (control), 7 th day, 14th day and 21 st day respectively of hormonal induction. The alveoli with larger diameter were significantly more on the 21 st day of hormonal induction as compared to 0 days of hormonal induction.

\subsection{Volume of Alveoli}

The volume of the alveoli was derived from those which were measured for their diameter. The volume of alveoli was $99.547 \times 10^{5}, 304.98 \times 10^{5}, 904.72 \times 10^{5}$ and $2032.45 \times 10^{5}$ cu. $\mu \mathrm{m}$. The volume of alveoli was significantly higher in the 21 st day of hormonal treated animal as compared to that of control.

\subsection{Length and Width of Lobules}

The lobules of the lactating gland were oval, oblong or elliptical in shape. The average length and width of lobules differed between different stages of hormonally induced buffaloes. The average length and width of lobules in the induced lactating buffaloes are presented in Table 1. The values of length of lobules were significantly higher at $21 \mathrm{st}$ day $\left(1.1329 \mu \mathrm{m} \times 10^{3}\right)$ as compared to 0 day $\left(0.4627 \mu \mathrm{m} \times 10^{3}\right)$, 7 th day $(0.7684$ $\left.\mu \mathrm{m} \times 10^{3}\right)$ and 14 th day $\left(1.0469 \mu \mathrm{m} \times 10^{3}\right)$. The values of width of lobules were also significantly higher at $21 \mathrm{st}$ day $\left(1.1098 \mu \mathrm{m} \times 10^{3}\right)$ as compared to 0 day $(0.3593$ $\left.\mu \mathrm{m} \times 10^{3}\right), 7$ th day $\left(0.5744 \mu \mathrm{m} \times 10^{3}\right)$ and 14 th day $(1.0292$ $\left.\mu \mathrm{m} \times 10^{3}\right)$. The length of lobules ranged from 0.322 $\mu \mathrm{m} \times 10^{3}$ to $1.275 \mu \mathrm{m} \times 10^{3}$ with an overall average of $0.8649 \mu \mathrm{m} \times 10^{3}$, whereas the width of the lobules ranged from $0.292 \mu \mathrm{m} \times 10^{3}$ to $1.215 \mu \mathrm{m} \times 10^{3}$ with an overall average value of $0.7555 \mu \mathrm{m} \times 10^{3}$.

\subsection{Number of Alveoli per sq $\mathrm{mm}$ Cross Sectional Area}

The average values of number of alveoli per 0.0770078 sq.mm cross sectional area have been presented in Table 1. The average number of alveoli per $\mathrm{mm}^{2}$ area of a lobule in different stages of estrogen and progesterone treatment in non-lactating buffaloes ranged from 82-184. The average values of number of alveoli per sq.mm area was significantly higher in 7th day (113), 14 th day (160) and 21 st day (184) compared to 0 day (82) of estrogen-progesterone treatment.

\subsection{Histomorphological Study (Microstructure)}

On 0 day of hormonal induction stage the stroma was in abundance, while parenchyma was restricted to a localized area in the form of lobules of irregular size. In some animals during this stage even adipose tissue as well as facia was observed in abundance (Fig. 1). There was no evidence of eosinophilic staining secretory material in the lumen or in the large ductal lumens. By the 7 th day of hormonal induction several changes in the area of components of mammary tissue were observed. The parenchyma rapidly took over the stroma in development. The epithelial cell area had developed more and distinct Lumina presented evidence of eosinophilic staining material within them. 
H.H. Mehta et al. / American Journal of Animal and Veterinary Sciences 8 (2): 66-72, 2013

Table 1. Number, volume, diameter of alveoli and lobules of different stages of hormonally treated surti buffalo

\begin{tabular}{llcccr}
\hline Parameter & & $\begin{array}{l}\text { Dth day of } \\
\text { Induction }\end{array}$ & $\begin{array}{l}\text { 7th day of } \\
\text { Induction }\end{array}$ & $\begin{array}{l}\text { 14th day of } \\
\text { Induction }\end{array}$ & $\begin{array}{c}\text { 21st day of } \\
\text { Induction }\end{array}$ \\
\hline No. of Alveoli & & 82.000 & 113.000 & 160.0000 & 184.000 \\
Volume of alveoli $\left(\mu \mathrm{m}^{3}\right) \times 10^{5} \mu \mathrm{m}$ & & 99.540 & 305.680 & 904.7200 & 2032.450 \\
Diameter of Alveoli $(\mu \mathrm{m}) \times 10^{3} \mu \mathrm{m}$ & Length & 0.621 & 0.844 & 1.2140 & 1.599 \\
& Width & 0.530 & 0.827 & 1.1880 & 1.546 \\
Diameter of lobules $(\mu \mathrm{m}) \times 10^{3} \mu \mathrm{m}$ & Length & 0.463 & 0.768 & 1.0470 & 1.133 \\
& Width & 0.359 & 0.574 & 1.0292 & 1.110 \\
\hline
\end{tabular}

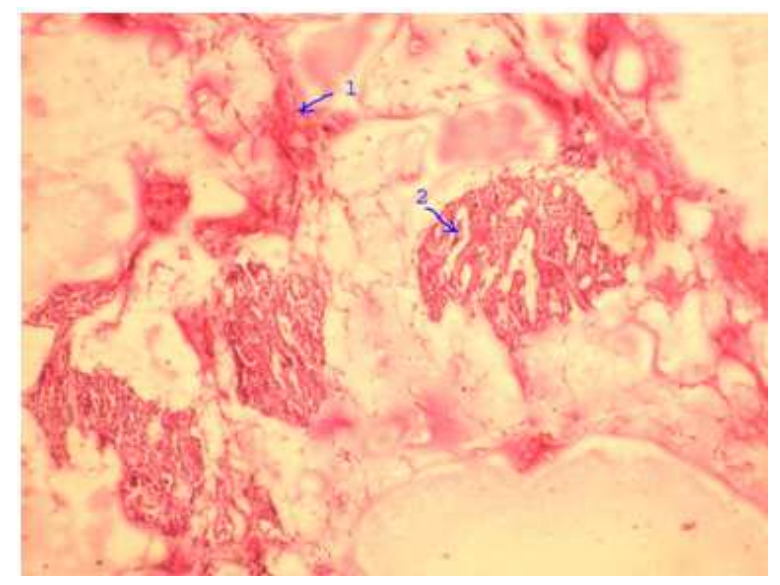

Fig. 1. Histomorphology of Mammary Gland on 0th Day of Hormonal Induction: (1). Stroma is in abundance. (2). Parenchyma is restricted to a localized area in the form of tubules of irregular size. Most of the tubules are collapsed. The epithelium of the tubules was low to high cuboidal in type

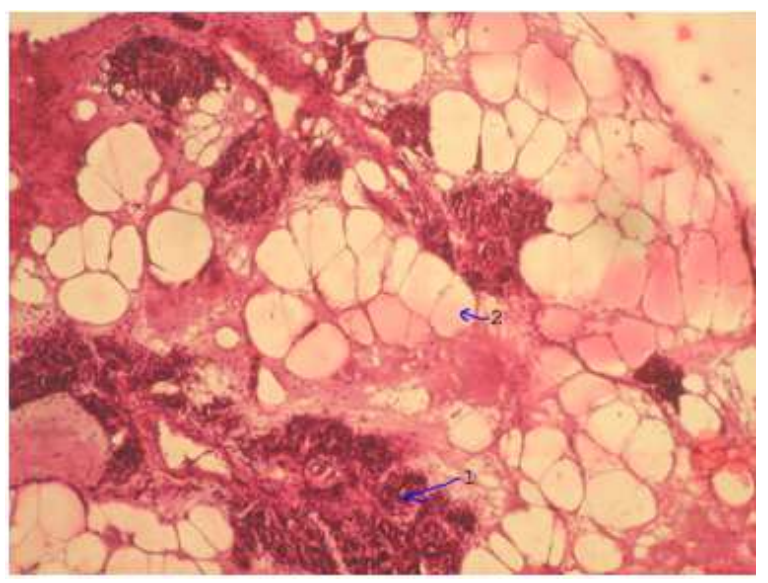

Fig. 2. Histomorphology of Mammary Gland on 7th Day of Hormonal Induction: (1). Organized lobules with proliferation of tubules inside in the adipose cells or fat cells. The Tubules are variable in size with or without lumen. (2). Fat cells are well observed

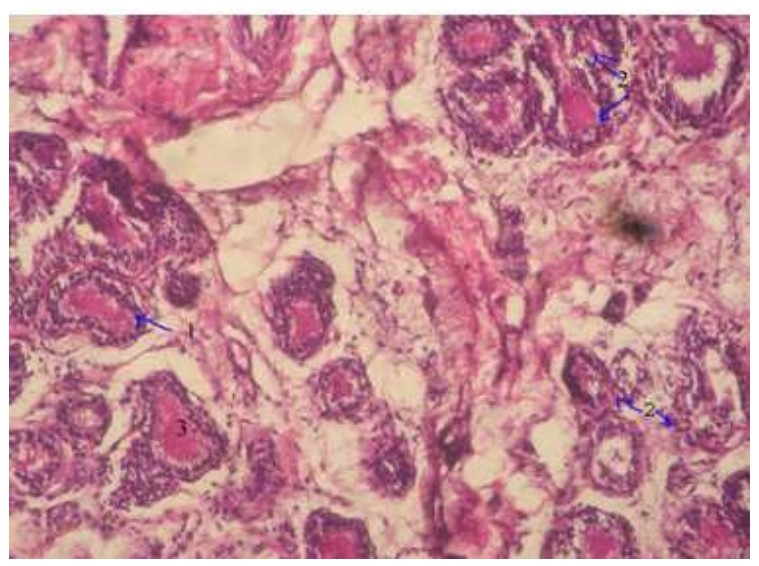

Fig. 3. Histomorphology of Mammary Gland on $14^{\text {th }}$ Day of Hormonal Induction: (1). Tubules are relatively more organized lined by cuboidal epithelium and completely developed lumen inside, (2). Proliferation of the tubule is comparatively more, (3). The tubules are well lumenized and found filled up with the eosinophilic material inside

Lobules were organized with the proliferation of tubules inside the adipose tissue or fat pad. Larger ducts lined by double layered epithelium were also evident. Lobules were of variable sized. The epithelial cells lining was of cuboidal to low columnar in type (Fig. 2).

Between day seven and fourteen, there was a concomitant increase in the epithelial and luminal area and decrease of stroma. Parenchyma was highly proliferated whereas lobules were relatively more organized with the complete development of lumen inside. A large number of infiltrating cells (lymphocytes) were found in the intertubular space. The tubules were lined by cuboidal type epithelium whereas; in some places even flat epithelium was found. Tubules were well lumenized and some were found with the eosinophilic secretory material inside (Fig. 3).

In mammary tissue of 21 st day of induction epithelial area was almost doubled as compared to day 0 and corresponding increase of luminal area and decrease in stroma. Lobules were highly developed and tightly packed with less interalveolar connective tissue. 


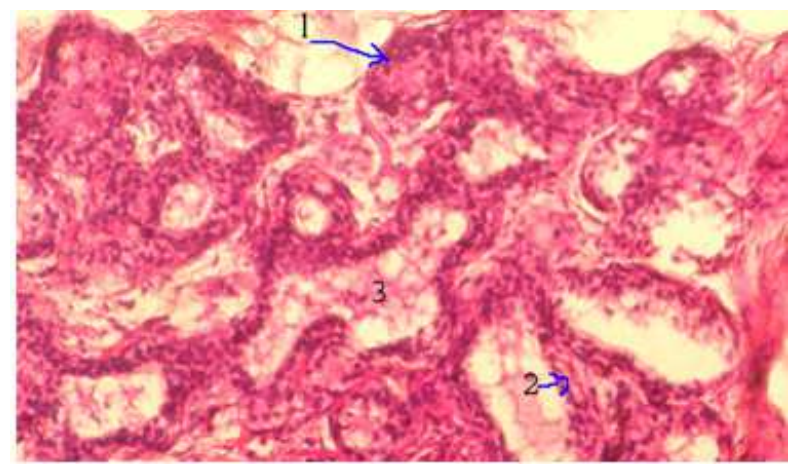

Fig. 4. Histomorphology of Mammary Gland on 21st Day of Hormonal Induction: (1). Cells are cuboidal to low columnar in type, (2). Tubules are highly developed with less intertubular space, (3). There are secretory eosinophilic substances observed in the lumen of the few tubules

The stroma was comparatively less. In all the lobules prominent secretory cells were present. They were showing eosinophilic secretory material in their lumen. The linings of epithelium cells were squamous to cuboidal or low columnal in type. In one of the animal, even secretory material was also found in the secretory duct (Fig. 4).

\section{DISCUSSION}

Development and differentiation of mammary glands in the bovine is characterized by epithelial cells proliferation, lobuloalveolar system development and lactogenesis. These changes are product of complex of steroid and protein hormones (Fleming et al., 1986).

In micrometric study during hormonal induced lactogenesis, a progressive change was observed in the development and differentiation of mammary gland (Table 1, Fig. 1 and 2). In the year, Parekh (2002) reported that lactating buffaloes have average smaller diameter of alveoli ranging from 15.90 to $145.75 \mu \mathrm{m}$ and the average of the larger diameter of alveoli in all lactating buffaloes ranged from 40 to $212 \mu \mathrm{m}$. She also stated that the length of the lobules ranged from 0.45 $\mu \mathrm{m} \times 10^{3}$ to $0.99 \mu \mathrm{m} \times 10^{3}$ in lactating buffaloes. Sulochana et al. (1981) reported in goat that alveoli were ranged from 18 to $80 \mu \mathrm{m}$ in diameter and lobules were 0.5 to $1.5 \mathrm{~mm}$ in length and 0.5 to $1.0 \mathrm{~mm}$ in width. Patel et al. (2007a) reported that the smaller and larger diameter of alveoli increases as animal attains lactating stage. He also reported that the volume of alveoli is also more in lactating buffalo in comparison to dry buffalo. In present study the progressive change in the length and width of lobules, diameter and volume of alveoli were found to be increased with the development and differentiation of mammary gland during the hormonal treatment. On the $21 \mathrm{st}$ day of hormonal treatment, all parameters mentioned above, were higher than on the 0th day of hormonal induction.

The process of lactogenesis is directly related to the number of alveoli. It was reported that the overall average number of alveoli per sq. $\mathrm{mm}$ area of lobule in a lactating buffalo was 100.56 (Parekh, 2002). In this study a progressive change (82-184) was observed in the average number of alveoli per sq.mm from 0th day to 21 st day of hormonal induction. So, we may conclude that this might be due to the effects of the hormone estrogen and progesterone as well as glucocorticoid as they are key inducer of mamogenesis (Heald, 1974; Fleming et al., 1986; Tucker, 2000).

During Histomorphological study (Microstructure) on 0 day the biopsy structure was compatible with the observations by Croom et al. (1976) in non-lactating mammary tissue of cattle (Fig. 1). In almost all randomly selected microscopic fields, it was observed that stroma was in abundance with scattered and restricted parenchyma. Decrease of stroma and development of parenchyma with more developed epithelial cell area is evidence of proliferation of alveolar cells in the mammary tissue. Fleming et al. (1986) and Croom et al. (1976) also reported similar changes where they stated decrease in fat pad, increase in parenchyma of mammary tissue and few epithelial cells. In present study after a week of hormonal induction, the epithelial cells lining was of cuboidal to low columnar in type (Fig. 2). Topper and Freeman (1980) also reported that estrogen and progesterone hormones playing key roles in the development of mammary epithelial cells which was observed in this study (Fig. 2-4).

Croom et al. (1976) and Fleming et al. (1986) in their experimentation observed that on 16th day of hormonal induction there was extensive differentiation of mammary epithelial cells, with expanded lumina with secretion. Patel et al. (2007b) also observed same type of development in biopsy of pregnant animal mammary gland. In this study after two weeks (14 day) of hormonal treatment parenchyma was highly proliferated with well organized lobules. Lumen was completely developed inside the lobules and a large number of infiltrating cells (lymphocytes) were found in the intertubular space with eosinophilic secretory material in some of the well lumenized tubules (Fig. 3). Thus, it could be the effect of estrogen and progesterone administered to animals. 
Tucker (2000), stated that dexamethasone (glucocorticoid), plays a key role in differentiation of lobule-alveolar system of the mammary gland apart from estrogen and progesterone. He stated that estrogen acts in at least two ways for initiation of lactation: (1) in several species it caused the release of prolactin from the anterior pituitary gland into the blood which in turn, would initiate lactation; and (2) estrogen also increases the number of prolactin receptors in mammary cells which is another lactogenic event. His findings also inferred that exogenous progesterone synergized with estrogen induces lobule-alveolar growth. This was also supported by the observation that mammogenesis during pregnancy in cattle coincided with increased secretion of both estrogen and progesterone. In present study, on the 21 st day of hormonal induction (3 weeks), there was increase in luminal area and decrease in stroma. Lobules were highly developed and tightly packed with reduced inter-alveolar connective tissue. Almost all lobules were showing prominent secretory cells. Thus, it confirms that Dexamethasone along with estrogen and progesterone, not only aided in development of mammary gland structure but also played a key role in initiation of lactation.

\section{CONCLUSION}

At different stages of hormonal induction the mammary gland of buffaloes, started developing into lactating stage because of estrodiol-17 $\beta$ and progesterone treatment along with dexamethasone (Glucocorticoid). The non-secretory mammary gland morphology was changed to secretory mammary gland morphology.

\section{ACKNOWLEDGEMENT}

This study was funded by the Department of Biotechnology, Ministry of Science and Technology, Government of India (Grant No.BT/PR 5984/AAQ/01/228/2005, dated 9-05-2006). The authors would also like to acknowledge Dr Javed Khan and Dr R Subramanian for their esteemed guidance in preparation of the manuscript.

\section{REFERENCES}

Alifakiotis, T.A., K. Katanos, I. Hatjiminaoglou, N. Zervas and G. Zirfiridis, 1980. Induced lactation in dairy ewes by various brief hormone treatments. Dairy Sci., 63: 750-755. PMID: 7190162
Chakriyarat, S., H.H. Head, W.W. Thatcher, F.C. Neal and C.J. Wilcox, 1978. Induction of lactation: Lactational, physiological and hormonal responses in the bovine. J. Dairy Sci., 61: 1715-1724. DOI: 10.3168/jds.S0022-0302(78)83793-X

Collier, R.J., D.E. Bauman and R.L. Hays, 1975. Milk production and reproductive performance of cows hormonally induced into lactation. Dairy Sci., 58: 1524-1527. DOI: $\quad 10.3168 /$ jds.S00220302(75)84746-1

Croom, W.J., R.J. Collier, D.E. Bauman and R.L. Hays, 1976. Cellular studies of mammary tissue from cows hormonally induced into lactation: Histology and ultrastructure. J. Dairy Sci., 59: 1232-1246. DOI: 10.3168/jds.S0022-0302(76)84352-4

Delouis, C.D., J. Djiane, G. Kann, M. Terqui and H.H. Head, 1978. Induced lactation in cows and heifers by short-term treatment with steroid hormones. Ann. Biol. Anita Biochem. Biophys., 18: 721-734. DOI: 10.1051/rnd: 19780410

Erb, R.E., E.L. Monk and C.J. Callahan, 1975. Salvaging infertile dairy cows by inducing lactation with hormones. Dairy Sci. Handbook.

Fleming, J.R., H.H. Head, K.C. Bachman, H.N. Becker and C.J. Wilcox, 1986. Induction of lactation: Histological and biochemical development of mammary tissue and milk yields of cows injected with estradiol-17 beta and progesterone for 21 days. Dairy Sci., 69: 3008-3021. PMID: 3558919

Head, H.H., C. Delouis, M. Terqui, G. Kann and J. Djiane, 1975. Hormonal induction of lactation in sheep. Dairy Sci., 58: 140-140.

Heald, C.W., 1974. Hormonal effects on mammary cytology. J. Dairy Sci., 57: 917925. PMID: 4368778

Howe, J.E., C.W. Heald and T.L. Bib, 1975. Histology of induced bovine lactogenesis. J. Dairy Sci., 58: 853-860. PMID: 1170220

Humason, G.L., 1967. Animal Tissue Techniques. 2nd Edn., W.H. Freeman and Co., San Francisco, pp: 569.

Jones, R.M., 1966. Basic Microscopic Technics. 5th Edn., University of Chicago Press, Chicago, pp: 334.

Koringa, P.G., A.K. Patel, K.N. Nandasana, U.V. Ramani and C.D. Bhong et al., 2008. Mammary gland biopsy in pregnant and lactating buffaloes in standing position. Ind. J. Vet. Surgery, 29: 50-51.

Meites, J., 1961. Hormonal Induction of Lactation and Galactopoiesis. In: Milk: The Mammary Gland and its Secretions, Kon, S.K. (Ed.), Academic Press, New York. 
Panchal, K.M. and Y.L. Vyas, 2005. The anatomy of udder of Buffalo: A complete monologue. Anand Agricultural University.

Parekh, B.H., 2002. Gross and microscopic studies on the udder of lactating and non-lactating, nonpregnant adult buffaloes (Bubalus bubalis). M.Sc. Thesis Submitted to Gujarat Agricultural University.

Patel, A.K., P.G. Koringa, K.N. Nandasana, U.V. Ramani and Barvalia et al., 2007a. Effect of bovine aomatotropin (bST) administration on the histology of mammary gland in lactating buffalo. Ind. J. Vet. Anatomy, 19: 22-28.

Patel, A.K., P.G. Koringa, K.N. Nandasana, U.V. Ramani and K.M. Panchal et al., 2007b. Comparative histology of mammary gland in Heifer, Pregnant, Lactation and Dry buffaloes. J. Ind. Vet. Anatomy, 19: 71-78.

Sanders, B.J., 1972. Animal Histology Procedures of the Pathological Technology Section of the National Cancer Institute. 1st Edn., For Sale by the Supt. of Docs., pp: 185.

Smith, K.L. and F.L. Schanbacher, 1973. Hormone induced lactation in the bovine. I. Lactational performance following injections of 17/-estradiol and progesterone. J. Dairy Sci., 56: 738-43. DOI: 10.3168/jds.S0022-0302(73)85243-9

Smith, K.L., D.R. Redman and F.L. Schanbacher, 1973. Efficiency of $17 \beta$-estradiol and progesterone treatment to initiate lactation in infertile cows. J. Dairy Sci., 56: 657-657.
Smith, K.L., L.A. Muir, L.C. Ferguson and H.R. Conrad, 1971. Selective transport of IgGl into the mammary gland: Role of estrogen and progesterone. J. Dairy Sci., 54: 1886-1894. DOI: $10.3168 /$ jds.S00220302(71)86130-1

Sulochana, S., M. Haffezuddin and U.B. Singh, 1981. Histological and histochemical studies of the mammary gland of the Indian goat (Capra hircus). Haryana Agric. Univ. J. Res., 11: 287-291.

Topper, Y.J. and C.S. Freeman, 1980. Multiple hormone interactions in the developmental biology of the mammary gland. Physiol. Rev., 60: 1049-1106. PMID: 7001510

Tucker, H.A., 1969. Factors affecting mammary gland cell numbers. J. Dairy Sci., 52: 720-729. PMID: 5391061

Tucker, H.A., 1971. Hormonal response to milking. J. Anim. Sci., 32: 137-141.

Tucker, H.A., 1974. General Endocrinological Control of Lactation. In: Lactation: A Comprehensive Treatise, Larson, B.L. and V.R. Smith (Eds.), Academic Press, New York, ISBN-10: 0124367038.

Tucker, HA., 2000. Symposium: Hormonal regulation of milk synthesis Hormones, Mammary Growth and Lactation: A 41 year perspective. J. Dairy Sci., 83: 874-884. 